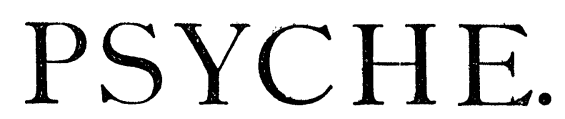

ORGAN OF THE CAMBRIDGE ENTOMOLOGICAL CLUB EDITED BY B. PICKMAN MANN.

\begin{tabular}{lll}
\hline \hline Vol. I.] Cambridge, Mass., March, 1876. [No. 23. \\
\hline \hline
\end{tabular}

\title{
List of Coleoptera collected in Michigan in 1874.
}

Among a large number of species of Coleoptera collected in Michigan by Mr. H. G. Hubbard and myself, during the year 1874, those mentioned in the following list will be found of some interest. Where no locality is given, the species were collected in the vicinity of Detroit.

Omophron robustum Horn. A single specimen on the shore of Lake Erie near Monroe, in September.

Schizogenius ferrugineus Putz. With the preceding, not rare.

Dicaelus purpuratus Bon. The larva of this species is very beautifully colored, and was found in rotten $\log s$, in the middle of August; it undergoes its transformation in this place, and the imago appears about the beginning of September.

Bembidium anguliferum Lec. ${ }^{1}$ Very rare under decaying leaves; previously found only in California.

Hydroporus rotundatus Lec. In the Detroit River, rare.

Helophorus tuberculatus Gyllh. Not common near Detroit.

Philhydrus consors Lec. Much rarer than Ph. cinctus Say.

Cercyon unipunctatum Linn. and C.centrimaculatum St. Not rare, on the window of a stable, in October.

Cercyon naviculare Zimm. Abundant in decaying fungus.

Nossidium americanum Mots. ${ }^{2}$ In a kind of Polyporus not rare in July.

Plilium Collani Mäkl. Common in decaying fungus.

Smicrus filicornis Fairm. Under decaying hay, in October, not rare.

Pteryx balteata Lec. In rotten wood and sphagnum moss, not rare.

Ptinclla quercus Lec. Under old bark of oak, elm and other trees, common.

Homalota Mannh. To give some idea of the number of species of this

1 For the determination of this and many of the following species I am indebted to Dr. Leconte.

2 It may be not without interest to state that a species of Motschulskium, very probably identical with $M$. sinuatocolle Matth., was found abundantly by $\mathrm{Mr}$. Crotch at San Diego, Cal., under seaweed. 
genus, inhabiting the United States, it may be stated that about sixty species were found in the vicinity of Detroit in a single season.

Calodera Mannh. Of this genus, which is very easy to recognize, three species were found near Detroit; three others are not rare in the marshes near Cambridge, Mass.; all the species live under very wet decaying leaves and moss.

Oligota pedalis Lec. Very rare under decaying leaves.

Myllaena fuscipennis Kr. Not rare under stones, etc., near the Detroit Riv.

Dinopsis americana $\mathrm{Kr}$. Under decaying leaves in fall and winter, not rare.

" myllaenoides $\mathrm{Kr}$. With the preceding, but much rarer.

Tachyporus nanus Er. aud T. maculipennis Lec. Both are common in the grass at the foot of old oak trees.

Tachyporus affinis Kirb. Kare in decaying fungus.

Conosoma Knoxii Lec. Not rare in fungus, in the fall.

Bolitobius niger Grav. Very rare in fungus.

Bryoporus rufescens Lec., B. testaceus Lec., Mycetoporus lepidus Grav., $M$. americanus Er. and $M$. lucidulus I.ec., occur rarely under decaying leaves; M. flavicollis Lec. is common in the same localities.

Heterothops fumigatus Lec. ${ }^{1}$ Common under decaying leaves.

" pusio Lec. Very rare.

Philonthus blandus Grav. and Ph. laetulus Say are two quite distinct species; both are to be found not rarely in fungus.

Xantholinus cephalus Say. Common under bark of several kinds of trees.

Thinobius Kr. A single specimen of an undescribed species was found by sweeping on a swampy meadow; a second species occurs in California.

'Trogophloeus Mannh. This genus seems to be very rich in species, fifteen or sixteen species being observed by us near Detroit.

Isomalus pallidus Lec. A single specimen in a little ditch, after a heavy rainstorm.

Pseudopsis sulcata Newm. Several specimens in decaying fungus.

Bythinus zonatus $\mathrm{Br}$. Two specimens sifted from sphagnum moss.

Trimium dubium Lec. Not very rare under dry old leaves.

Catops brunneipennis Mannh. Several specimens under decaying leaves.

Colon dentatum Lec. and two other species of the same genus, Anisotoma punctatostriata Kirb., A. collaris Lec., A. obsoleta Melsh., Cyrtusa egena Lec., C. picipennis Lec., Colenis impunctata Lec., Clambus gibbulus Lec., Cybocephalus nigritulus Lec., etc., are found by sweeping meadows at sunset, in the latter part of June.

Anogdus laevis Lec. Several specimens under old bark, in August.

Clambus puberulus Lec. On a window of a stable, not rare, in August.

Orthoperus glaber Lec. and two other species of the same genus, by sweeping on grass.

Baeocera concolor Fabr. and B. apicalis Lec. Rare in fungus.

${ }^{1}$ An undescribed species of Tanygnathus Er. occurs in Florida. 
Toxidium gammaroides Lec. and T. compressum Zimı. Not rare in the same localities.

Lathiridius oarinatus Gyllh. Common on a window of a stable.

Lathridius filiformis Aub. Common in old flour barrels, in company with Mycetophagus bipustulatus Melsh. and Cryptophagus croceus Zimm.

Mycetophagus obsoletus Melsh. One specimen, under leaves. " pluripunctatus Lec. Abundant in fungus.

Litargus infulatus Lec. One specimen, under bark.

Mycotretus sanguinipennis Say and M. pulcher Say. Not rare in a small kind of fungus growing on old logs.

Triplax festiva Lec. and T. macra Lec. A large colony of both species was found in the end of August, inhabiting a fungus growing on a dead beech tree, in company with Engis 4-maculata Say, Triplax thoracica Say, T. flavicollis Lec., Diplocoelus brunneus, Orchesia castanea Melsh. and other species.

Laemophloeus adustus Lec. Rare in sweeping on meadows.

Monotoma fulvipes Melsh., $M$. parallela Lec., $M$. picipes Herbst. The two former rarely and occasionally, the latter common on a window of a stable.

Lithochrus immaculatus Zimm. Very rare on meadows.

Onthophilus alternatus Say. Quite common in the sand under decaying fungus and excrements, but very difficult to be seen.

Dendrophilus punctulatus Say. In old trees, rarely.

Nicagus obscurus Lec. This species was common on the 20th of June, flying in the early afternoon, on the shore of Lake Huron, above Port Huron.

Tharops obliquus Say. Abundant on piles of beech wood, in July and Aug.

Nematodes penetrans Lec. A single specimen.

Cardiophorus amictus Melsh. and C. convexulus Lec. Rare near Detroit and Port Huron.

Helodes explanata Lec. Only one specimen on a meadow, in July.

Eucinetus terminalis Lec. and $E$. testaceus Lec. rare under dry leaves; E. morio Lec. not rare in fungus.

Polemius limbatus I.ec. Rare on meadows.

Hydnocera tabida Lec. Several specimens on grass, near the Detroit River.

Caenocera scymnoides Lec. One specimen by sweeping.

Cryptocephalus Schreibersii Suffr. Rare on Cassandra calyculata, in Oct.

Stenispa collaris Baly. Several specimens of this rare insect were found under dry leaves near willows, in October.

Haplandrus concolor Lec. One specimen on the shore of Lake Huron near Port Huron.

Paratenetus gibbipennis Mots. Not rare under decaying leaves. This species is stouter than $P$. fuscus Lec., with the elytra almost gibbous and the pubescence much shorter.

Pentaphyllus pallidus Lec. Abundant in dry fungus. 
Anthicus coracinus Lec. A few specimens under decaying hay, in Oct. Eustrophys confinis Lec. Not rare with E. bicolor Say and E. tomentosus S. Glipodes sericans Lec. Two specimens by sweeping.

E. A. Schwarz.

\section{BIBLIOGRAPHICAL RECORD.}

Authors and Societies are requested to forward their works to the Editor at the earliest date possible. We ask our readers to inform us of the publication especially of those works which are not generally consulted by entomologists.

B. Pickman Mann.

(Continued from page 113.)

* 381. The Observer of Nature, vol. i, contains the following, and Nos. 382 to 392.

a. Brief notes [of interest, but not demanding special reference] upon donations of insects to the Kansas State University and upon the diligence and success of students and collectors belonging to the University, Nos. $1,2,3,4$. b. Abundance of Lygaeus leuropterus, No. 2. c. University Cabinet [extent of the entomological collection], No. 3. d. The Curculio [habits of Conotrachelus nenuphar], No. 4.

* 382. Andrew Atchison. The First Naturalist. No. 1. Biographical sketch of Aristotle.

* 383. George F. Gaumer. Insects and How to Collect them. No. 1.

Directions for collecting insects.

* 384. G. F. Gaumer. Collecting in Southern Kansas. No. 1.

Notes upon the habits of the tarantula, scorpion and centipede.

* 385. Anonym. How to Collect. No. 2.

Habits of Coleoptera; how to collect and preserve them.

* 386. F. H. SNow. List of Butterflies occurring at Lawrence, Kansas, with notes. No. 2.

List of 66 species; notes on their abundance and food-plants.

* 387. F. H. Morgan. Coleoptera in Lawrence Mills. No. 3.

Notes on habits of seven species found in flour-mills.

* 388. G. F. Gaumer. Nature's Common Things. No. 3.

Notice of a few insects occurring near Lawrence.

* 389. W. H. Edwards. Butterflies. No. 4.

Letter to Prof. Snow, upon varieties and the rearing of butterflies.

* 390. A. Atchison. The Maple Worm. No. 4.

Habits, food-plants (Acer spp.) and parasites of Anisota rubicunda. [See also vol. ii, No. 4 .] 

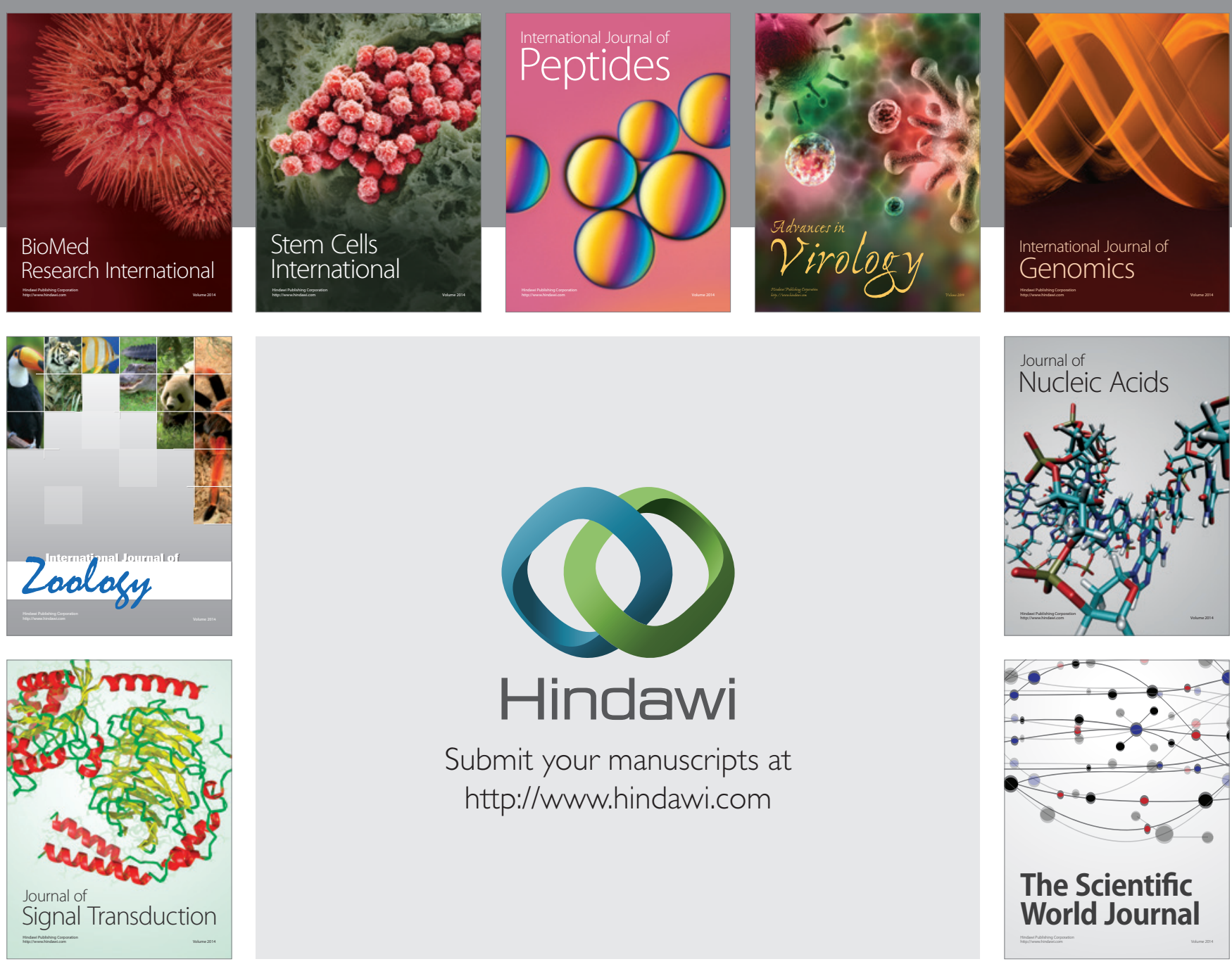

Submit your manuscripts at

http://www.hindawi.com
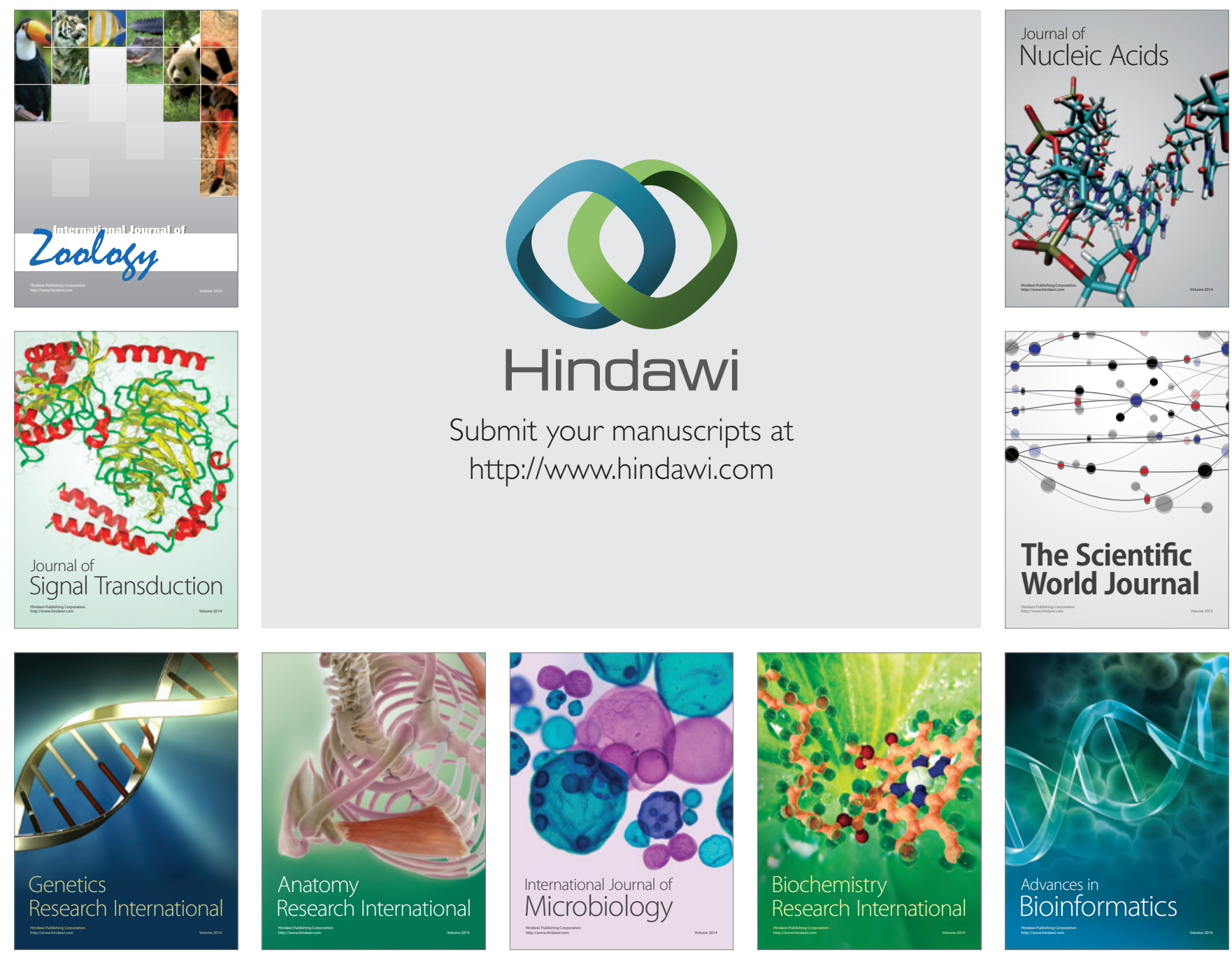

The Scientific World Journal
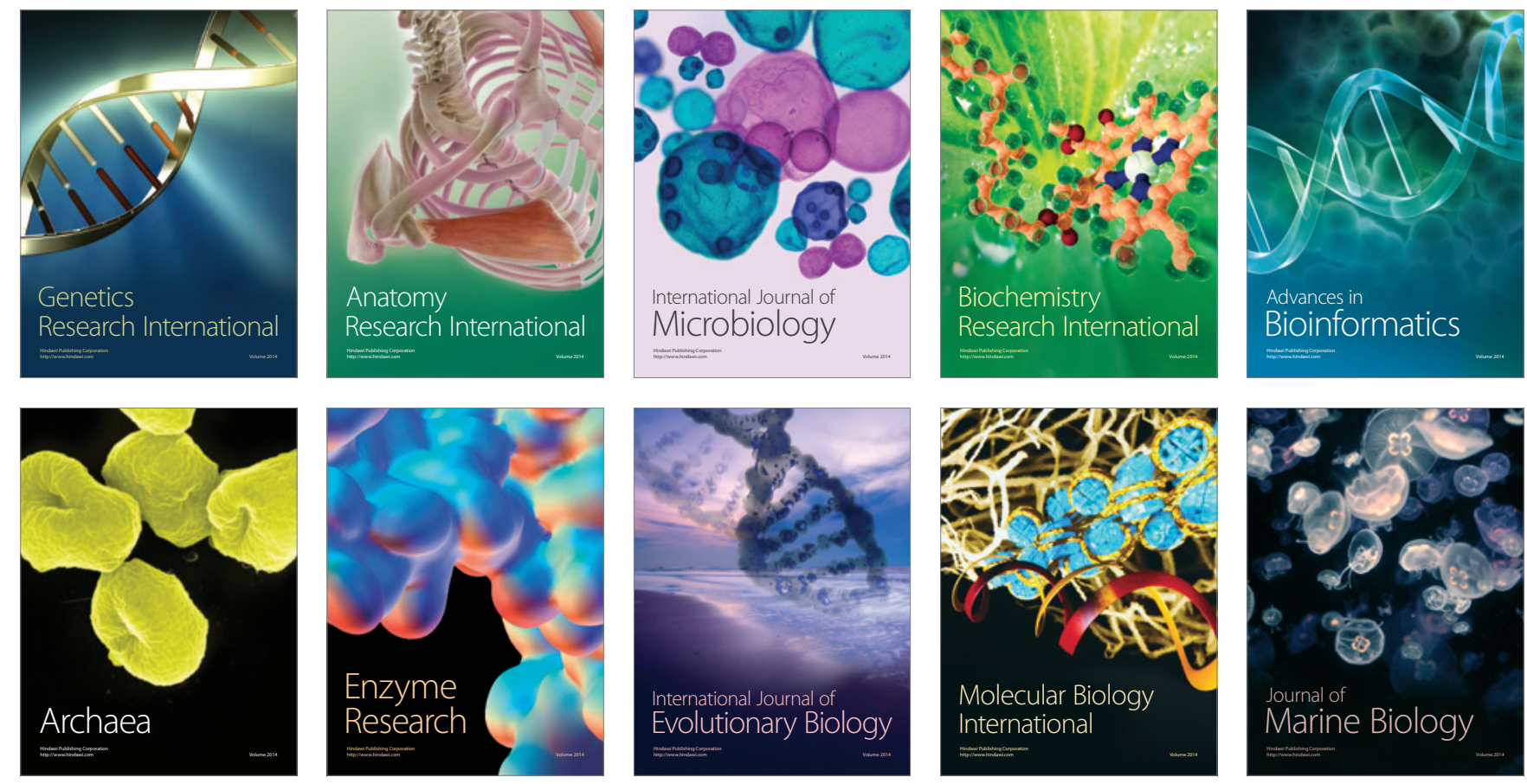